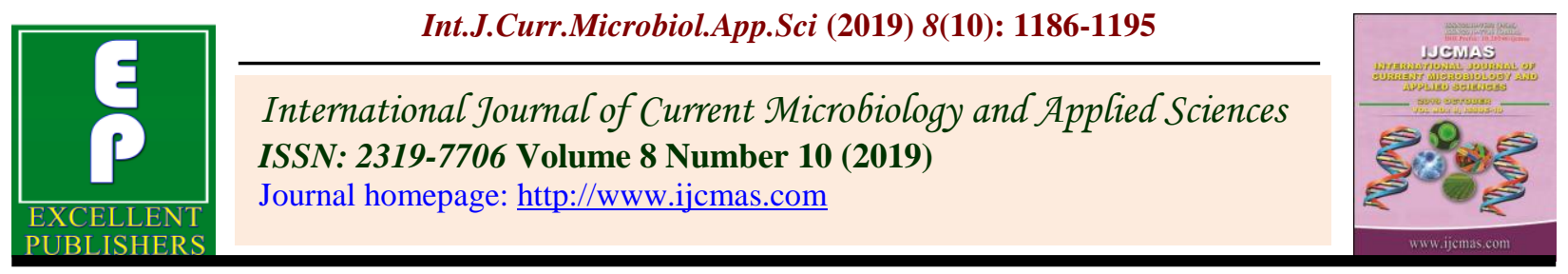

Original Research Article

https://doi.org/10.20546/ijcmas.2019.810.139

\title{
Performance of Sunflower in Relation to Soil Types and Management Levels
}

\author{
V. Ramamurthy ${ }^{1 *}$, G.D. Satish Kumar ${ }^{2}$, M.A. Aziz Qureshi ${ }^{2}$ and B.P. Bhaskar ${ }^{1}$ \\ ${ }^{1}$ ICAR-NBSS \& LUP, Regional Centre, Bangalore-560024 \\ ${ }^{2}$ ICAR-Indian Institute of Oilseeds Research, Hyderabad-500030, India \\ *Corresponding author
}

\section{A B S T R A C T}

\begin{tabular}{|c|}
\hline Keywords \\
\hline $\begin{array}{l}\text { Sunflower, Black } \\
\text { soils, Red soils, On- } \\
\text { farm trials, Best } \\
\text { management } \\
\text { practice }\end{array}$ \\
\hline Article Info \\
\hline $\begin{array}{l}\text { Accepted: } \\
\text { 10 September } 2019 \\
\text { Available Online: } \\
10 \text { October } 2019\end{array}$ \\
\hline
\end{tabular}

\section{Introduction}

Sunflower (Helianthus annuus L.) is one of the most important oilseed crop containing 3949 per cent edible oil, 14-19 per cent protein and 7.5 - 9.4 per cent of soluble sugars. Sunflower crop was introduced to India during 1969 to bridge the gap of recurring edible oil shortage in the country. The commercial cultivation of sunflower started in India during 1972-73 with a few imported varieties from USSR and Canada. Now, the crop has been well accepted by the farming community because of its desirable attributes such as short duration, photoperiod insensitivity, adaptability to wide range of soil and climatic conditions, drought tolerance, lower seed rate, high seed multiplication rate and high quality of edible oil (Byrareddy et al., 2007; Kaya and Kolsarici, 2011). In India, it is grown in 5.9 lakh hectares with an annual production of 4.34 lakh tonnes having productivity of 736 $\mathrm{kgha}^{-1}$ (MoA, 2015). Sunflower is traditionally cultivated in Karnataka $(63 \%$ area with average .yield of $583 \mathrm{~kg} / \mathrm{ha}$ ), Andhra Pradesh (17\% area with average. yield of $732 \mathrm{~kg} / \mathrm{ha}$ ) and Maharashtra (6\% area with average. yield of $382 \mathrm{~kg} / \mathrm{ha}$ ) which together make 86 per cent of country's area. Currently, the area under sunflower has decreased significantly as 
compared to 1993-94 and its lower profitability compared to many other competing crops is a serious concern. The reasons ascertained for wide gap between national and global level productivity and profitability, are: cultivation in marginal and sub-marginal lands, poor management practices under rainfed cultivation, suboptimal and imbalanced nutrition and poor seed setting and high per cent of chaffy seeds in the centre of the capitulum. Balanced nutrient management and micronutrients play a major role in increasing seed setting percentage and its influence on growth and yield. Among the micronutrients, boron and zinc play an important role in seed setting and yield of sunflower. Boron can influence photosynthesis, respiration, activate number of enzymatic systems of protein and nucleic acid metabolism in plants (Kibalenko, 1972). Zinc plays multiple important roles in activating more than 300 enzymes in plants, in auxin synthesis and protein synthesis. With this background, on farm trials were initiated to demonstrate impact of Best Management Practices (BMP) in comparison to Farmers Practice (FP) in sunflower dominant areas of Badami tehsil of Bagalkote and Koppal tehsil, where sunflower is grown on distinct soil types.

\section{Materials and Methods}

\section{Location and Agro-climate of the study area}

Present study carried out in Mangalur and Gonal villages of Badami tehsil of Bagalkote district and Betegeri village of Koppal tehsil and district (Fig. 1). Agro climatically, both Badami and Koppal tehsils comes under northern dry zone of Karnataka Plateau with an average rainfall of $570 \mathrm{~mm}$ but differs with length of growing period (LGP). Badami is having < 90 days LGP whereas Koppal has LGP of 90-120 days (Naidu et.al, 2006). The seasonal distribution of rainfall shows that $66 \%$ of the annual rainfall is received during south west monsoon (June - September) and, $21 \%$ during post-monsoon period (October December). The annual average number of rainy days is 41 .

The soils of experimental sites are located in Mangalure and Gonal villages are dominated by Vertisols (TypicHaplusterts) (very deep black soils), whereas Betegeri village soils are very deep sandy clay loam (Alfisols), medium in nitrogen and high in phosphorus and potash. Soil physical and chemical properties of both the sites are presented in Table 1. Most of the black and red soils are neutral with high electrical conductivity $\left(0.04-2.03 \mathrm{dSm}^{-1}\right)$ and medium inorganic carbon (OC, 0.33-0.89 \%). Many on-farm test sites are found sufficient in available $\mathrm{K}_{2} \mathrm{O}, \mathrm{Ca}, \mathrm{Mg}, \mathrm{S}$ and micronutrients viz. $\mathrm{Cu}, \mathrm{Fe}$ and $\mathrm{Mn}$. However, most of the soils are having below critical limit of DTPA extractable $\mathrm{Zn}\left(0.02-0.09 \mathrm{mg} \mathrm{kg}^{-1}\right)$ and Boron (0.10-0.48 $\left.\mathrm{mg} \mathrm{kg}^{-1}\right)$.

The sorghum, cotton and soybean are grown in kharif whereas wheat and chickpea as the rabi (winter). Farmers have little access to timely, affordable credit and adoption of agricultural inputs including fertilizer.

\section{Methodology}

On-farm trials in black (Typic Haplusterts) and red (Alfisols) soils were conducted in 10 farmer's field in each soil during rabi 2015-16 to 2016-17. Two popular cultivars i.e., KBSH53 in 2015-16 and KBSH- 44 in 2016-17 were sown in 2000 sq. $m$ to impose farmer's practice and Best Management Practice (BMP). In 2015-16, seeds were sown in the $1^{\text {st }}$ week of December, whereas in 2016-17 sowing was done at $3^{\text {rd }}$ week of November.

Best Management Practices (BMP) include seed treatment with imidachloroprid @6 
$\mathrm{g} / \mathrm{kg} /$, application of $5 \mathrm{t}$ FYM / ha, optimum seed rate $(5 \mathrm{~kg} / \mathrm{ha})$, thinning for optimum plant population, application of soil test based NPK with $\mathrm{Zn}$, boron spray at ray floret opening stage whereas, farmers practice (FP) comprises of planting at closer spacing $(30 \mathrm{x}$ $30 \mathrm{~cm}$ ) and application of two bags of DAP or one bag of urea. The data was analyzed by using factorial randomized block design (RBD) where soils were taken as first factor and management as second factor.

\section{Agro-economic analysis}

The cost of chemical fertilizers and seeds as prevailed in the market at the time of experimentation were used for agro-economic analysis. Labour expenses for different operations were calculated by considering existing wages. Treatment wise gross income was computed by multiplying the seed yield with the market price and expressed as total income per hectare. Net income was calculated by deducting the cost of cultivation from gross income. Cost benefit ratio was calculated by dividing the gross income by cost of cultivation.

\section{Results and Discussion}

Effect of soil types on yield and yield attributes of sunflower

There is a marked differences in yield attributes among the different treatments such as seed yield per plant (g/plant), number of seeds per head, number of filled seeds per head, test weight, chaffy seeds per head and seed yield (kg/ha) (Table 3).

Black (Typic Haplusterts) soils have recorded significantly the highest seed yield per plant (13.82, 13.09 and $13.44 \mathrm{~g}$ at 2015-16, 2016-17 and pooled data, respectively) over red (Alfisols) soil. Similar trends were recorded for rest of the yield attributes like number of filled seeds per head (352) and test weight $(4.52 \mathrm{~g})$ but significantly lowest per cent chaffy seeds $(14.29 \%)$ in black soils as compared to red soils. Total number of seeds per head was not significantly influenced in both the years. Productivity of sunflower in black soils significantly higher in 2015-16 (1024 kg/ha) and pooled data (996 kg/ha). Productivity in 2016-17 was not significantly differed due to soil types. However, red soils recorded higher seed yield of $981 \mathrm{~kg} / \mathrm{ha}$ over black soils. This may be due to rain free period (Table 2) from October on wards in black soils areas and crop was raised completely on limited irrigation facilities. Whereas, in red soils areas, there was good amount of rains $(139 \mathrm{~mm})$ in October, which helped in land preparation and with limited irrigation facilities, crop establishment was good. During 2016-17, there were no rains during crop growth (Table 2) and due to less incidence of powdery mildew, crop performance was good. Productivity of sunflower varied with soils, black soils recorded 18 to 7 per cent higher yield over red soils.

Effect of management on yield and yield attributes of sunflower

Further, BMP was recorded significantly highest seed yield per plant, total number of seeds per head, number of filled seeds per head, test weight in 2015-16, 2016-17 and pooled date as compared to farmers practice (Table 3). Farmers practice recorded significantly higher per cent chaffy seeds per head as compared to BMP. Significantly highest seed yield (1109 kg/ha) was observed in BMP as compared to FP (813 kg/ha). Higher seed yield in BMP is contributed by yield attributes like seed yield per plant, total number of seeds per head, number of filled seeds, test weight and lower chaffy seeds. 
Table.1 Physical and chemical properties of experimental soils

\begin{tabular}{|l|l|c|c|}
\hline SI. No & \multicolumn{1}{|c|}{ Properties } & \multicolumn{2}{|c|}{ Type of soil } \\
\hline $\mathbf{I}$ & \multicolumn{1}{|c|}{ Physical properties } & \multicolumn{1}{|c|}{ Black soil } & Red soil \\
\hline $\mathbf{1}$ & Soil type & Very deep clayey Vertisol & Very deep sandy clay loam \\
\hline & Drainage & Moderately well drained & Well drained soils \\
\hline & Slope & $1-3 \%$ & $1-3 \%$ \\
\hline & Erosion & Slightly eroded soil & Slight to moderately eroded soil \\
\hline $\mathbf{I I}$ & \multicolumn{1}{|c|}{ Chemical properties } & & 6.9 \\
\hline $\mathbf{1}$ & pH $(1: 2.5)$ & $6.4-8.5$ & $0.04-2.3$ \\
\hline $\mathbf{2}$ & EC $(\mathrm{dS} / \mathrm{m})$ & $0.03-0.25$ & $0.11-1.28$ \\
\hline $\mathbf{3}$ & OC $(\%)$ & $0.33-0.89$ & $4-55$ \\
\hline $\mathbf{4}$ & Available $\mathrm{P}\left(\mathrm{P}_{2} \mathrm{O} 5\right)(\mathrm{kg} / \mathrm{acre})$ & $4-20$ & $64-400$ \\
\hline $\mathbf{5}$ & Available $\mathrm{K}\left(\mathrm{K}_{2} \mathrm{O}\right)(\mathrm{kg} / \mathrm{acre})$ & $100-356$ & $0.9-175.9$ \\
\hline $\mathbf{6}$ & Available $\mathrm{Sulphur}(\mathrm{mg} / \mathrm{kg})$ & $1.85-83.3$ & $593.4-4573$ \\
\hline $\mathbf{7}$ & Available $\mathrm{Calcium}(\mathrm{mg} / \mathrm{kg})$ & $861.1-4911$ & $233.2-1885$ \\
\hline $\mathbf{8}$ & Available $\mathrm{Magnesium}(\mathrm{mg} / \mathrm{kg})$ & $199.8-1843$ & $0.02-18.09$ \\
\hline $\mathbf{9}$ & Available $\mathrm{Zn}(\mathrm{mg} / \mathrm{kg})$ & $0.09-14.66$ & $2.87-27.7$ \\
\hline $\mathbf{1 0}$ & Available $\mathrm{Fe}(\mathrm{mg} / \mathrm{kg})$ & $2.33-15.59$ & $0.68-2.46$ \\
\hline $\mathbf{1 1}$ & Available $\mathrm{Cu}(\mathrm{mg} / \mathrm{kg})$ & $0.79-2.45$ & $18.81-72.44$ \\
\hline $\mathbf{1 2}$ & Available $\mathrm{Mn}(\mathrm{mg} / \mathrm{kg})$ & $18.3-59.39$ & $0.22-0.44$ \\
\hline $\mathbf{1 3}$ & Available Boron $(\mathrm{mg} / \mathrm{kg})$ & $0.1-0.48$ & \\
\hline
\end{tabular}


Table.2 Rainfall (mm) distribution in Badami and Koppal districts

\begin{tabular}{|l|c|c|c|c|c|c|}
\hline $\begin{array}{c}\text { Year \& } \\
\text { Districts }\end{array}$ & \multicolumn{2}{|c|}{ October } & \multicolumn{2}{c|}{ November } & \multicolumn{2}{c|}{ December } \\
\hline Badami & Normal & Actual & Normal & Actual & Normal & Actual \\
\hline $\mathbf{2 0 1 5}$ & 111 & 49 & 25 & 01 & 09 & 00 \\
\hline $\mathbf{2 0 1 6}$ & 111 & 00 & 25 & 00 & 09 & 00 \\
\hline Koppal & & & & & & \\
\hline $\mathbf{2 0 1 5}$ & 113 & 19 & 24 & 00 & 07 & 00 \\
\hline $\mathbf{2 0 1 6}$ & 113 & 139 & 24 & 00 & 07 & 02 \\
\hline
\end{tabular}

Table.3 Yield and yield attributes of sunflower as influenced by soil and management practices

\begin{tabular}{|c|c|c|c|c|c|c|c|c|c|c|c|c|c|c|c|c|c|c|}
\hline \multirow{2}{*}{\begin{tabular}{|l} 
Factors \\
Soil type
\end{tabular}} & \multicolumn{3}{|c|}{ Seed yield per plant (g) } & \multicolumn{3}{|c|}{ Total number of seeds/head } & \multicolumn{3}{|c|}{ No. of filled seeds/head } & \multicolumn{3}{|c|}{ Test weight (g) } & \multicolumn{3}{|c|}{$\%$ Chaffy seeds/head } & \multicolumn{3}{|c|}{ Seed yield $\mathrm{kg} / \mathrm{ha}$} \\
\hline & $\begin{array}{l}2015- \\
16\end{array}$ & $\begin{array}{l}2016- \\
17\end{array}$ & $\begin{array}{l}\text { poole } \\
\text { d }\end{array}$ & $\begin{array}{l}2015- \\
16\end{array}$ & $\begin{array}{l}2016- \\
17\end{array}$ & pooled & $\begin{array}{l}2015- \\
16\end{array}$ & $\begin{array}{l}2016- \\
17\end{array}$ & pooled & $\begin{array}{l}2015 \\
-16\end{array}$ & $\begin{array}{l}2016- \\
17\end{array}$ & pooled & $\begin{array}{l}2015- \\
16\end{array}$ & $\begin{array}{l}2016- \\
17\end{array}$ & pooled & $2015-16$ & $\begin{array}{l}2016- \\
17\end{array}$ & pooled \\
\hline Black soil & 13.82 & 13.09 & 13.44 & 410.90 & 411.41 & 410.87 & 349.15 & 355.46 & 352 & 4.59 & 4.46 & 4.52 & 15.01 & 13.53 & 14.29 & 1024 & 970 & 996 \\
\hline Red soil & 11.66 & 13.24 & 12.51 & 403.10 & 418.27 & 410.85 & 336.75 & 351.91 & 344.72 & 4.56 & 4.58 & 4.57 & 16.45 & 15.91 & 16.11 & 863 & 981 & 927 \\
\hline CD@ $5 \%$ & 0.67 & 0.55 & 0.42 & NS & 8.46 & NS & 5.38 & NS & 4.35 & NS & 0.06 & 0.04 & NS & 1.5 & 0.93 & 49.43 & NS & 30.96 \\
\hline \multicolumn{19}{|c|}{ Management Practices } \\
\hline BMP & 14.46 & 15.39 & 14.97 & 412.80 & 425.55 & 420 & 355.85 & 372.32 & 364.52 & 4.59 & 4.56 & 4.57 & 13.79 & 12.38 & 13.15 & 1071 & 1140 & 1109 \\
\hline FP & 11.01 & 10.93 & 10.98 & 401.15 & 404.13 & 401.73 & 330.05 & 335.05 & 332.23 & 4.56 & 4.48 & 4.52 & 17.68 & 17.05 & 17.25 & 816 & 810 & 813 \\
\hline CD @ 5\% & 0.67 & 0.55 & 0.42 & 8.15 & 8.46 & 5.6 & 5.38 & 6.24 & 4.35 & NS & 0.06 & 0.04 & 1.45 & 1.5 & 0.93 & 49.43 & 40.89 & 30.96 \\
\hline \multicolumn{19}{|c|}{$\begin{array}{l}\text { Interaction of Soil x Management } \\
\text { practices }\end{array}$} \\
\hline $\begin{array}{l}\text { Black soil } \\
\text { x BMP }\end{array}$ & 15.93 & 14.47 & 15.22 & 417.70 & 409.18 & 413.95 & 366.60 & 365.64 & 366.35 & 4.61 & 4.54 & 4.57 & 12.21 & 10.59 & 11.45 & 1180 & 1072 & 1128 \\
\hline $\begin{array}{l}\text { Black soil } \\
\text { x FP }\end{array}$ & 11.71 & 11.71 & 11.66 & 404.00 & 413.63 & 407.8 & 331.70 & 345.27 & 337.7 & 4.56 & 4.39 & 4.48 & 17.81 & 16.46 & 17.11 & 868 & 867 & 864 \\
\hline $\begin{array}{l}\text { Red soil } x \\
\text { BMP }\end{array}$ & 13.00 & 16.31 & 14.72 & 407.90 & 441.91 & 426 & 345.10 & 379 & 362.7 & 4.56 & 4.59 & 4.57 & 15.37 & 14.14 & 14.84 & 963 & 1208 & 1091 \\
\hline $\begin{array}{l}\text { Red soil } x \\
\text { FP }\end{array}$ & 10.31 & 10.17 & 10.29 & 398.30 & 394.64 & 395.65 & 328.40 & 324.82 & 326.75 & 4.56 & 4.57 & 4.57 & 17.53 & 17.65 & 17.39 & 764 & 753 & 763 \\
\hline CD @ 5\% & 0.94 & 0.78 & 0.59 & NS & 11.96 & 7.93 & 7.60 & 8.83 & NS & NS & 0.08 & 0.06 & 2.05 & NS & 1.31 & 69.91 & 57.83 & 43.78 \\
\hline
\end{tabular}




\section{Int.J.Curr.Microbiol.App.Sci (2019) 8(10): 1186-1195}

Table.4 Economics of sunflower as influenced by soil and management practices

\begin{tabular}{|c|c|c|c|c|c|c|c|c|c|c|c|c|}
\hline \multirow{2}{*}{$\begin{array}{l}\text { Factors } \\
\text { Soil type }\end{array}$} & \multicolumn{3}{|c|}{ Cost of Cultivation (Rs/ha) } & \multicolumn{3}{|c|}{ Gross returns (Rs/ha) } & \multicolumn{3}{|c|}{ Net returns (Rs/ha) } & \multicolumn{3}{|c|}{$\mathrm{B}: \mathrm{C}$ ratio } \\
\hline & $2015-16$ & $2016-17$ & pooled & $2015-16$ & 2016-17 & pooled & $2015-16$ & $2016-17$ & pooled & $2015-16$ & 2016-17 & pooled \\
\hline Black soil & 15000 & 16000 & 15500 & 38912 & 36868 & 37890 & 23912 & 20868 & 22390 & 2.59 & 2.30 & 2.44 \\
\hline Red soil & 13000 & 14000 & 13500 & 32794 & 37278 & 35036 & 19794 & 23278 & 21536 & 2.52 & 2.66 & 2.60 \\
\hline \multicolumn{13}{|c|}{ Management Practices } \\
\hline BMP & 15000 & 16000 & 15500 & 40698 & 43320 & 42009 & 25698 & 27320 & 26509 & 2.71 & 2.71 & 2.71 \\
\hline FP & 13000 & 14000 & 13500 & 31008 & 30780 & 30894 & 18008 & 16780 & 17394 & 2.39 & 2.20 & 2.29 \\
\hline \multicolumn{13}{|c|}{ Interaction of Soil $x$ Management practices } \\
\hline $\begin{array}{l}\text { Black soil } x \\
\text { BMP }\end{array}$ & 15000 & 16000 & 15500 & 44840 & 40736 & 42788 & 29840 & 24736 & 27288 & 2.99 & 2.55 & 2.76 \\
\hline $\begin{array}{l}\text { Black soil } x \\
\text { FP }\end{array}$ & 13000 & 14000 & 13500 & 32984 & 32946 & 32965 & 19984 & 18946 & 19465 & 2.54 & 2.35 & 2.44 \\
\hline $\begin{array}{l}\text { Red soil } x \\
\text { BMP }\end{array}$ & 15000 & 16000 & 15500 & 36594 & 45904 & 41249 & 21594 & 29904 & 25749 & 2.44 & 2.87 & 2.66 \\
\hline Red soil x FP & 13000 & 14000 & 13500 & 29032 & 28614 & 28823 & 16032 & 14614 & 15323 & 2.23 & 2.04 & 2.14 \\
\hline
\end{tabular}


Fig.1 NARP zones of Karnataka with study locations

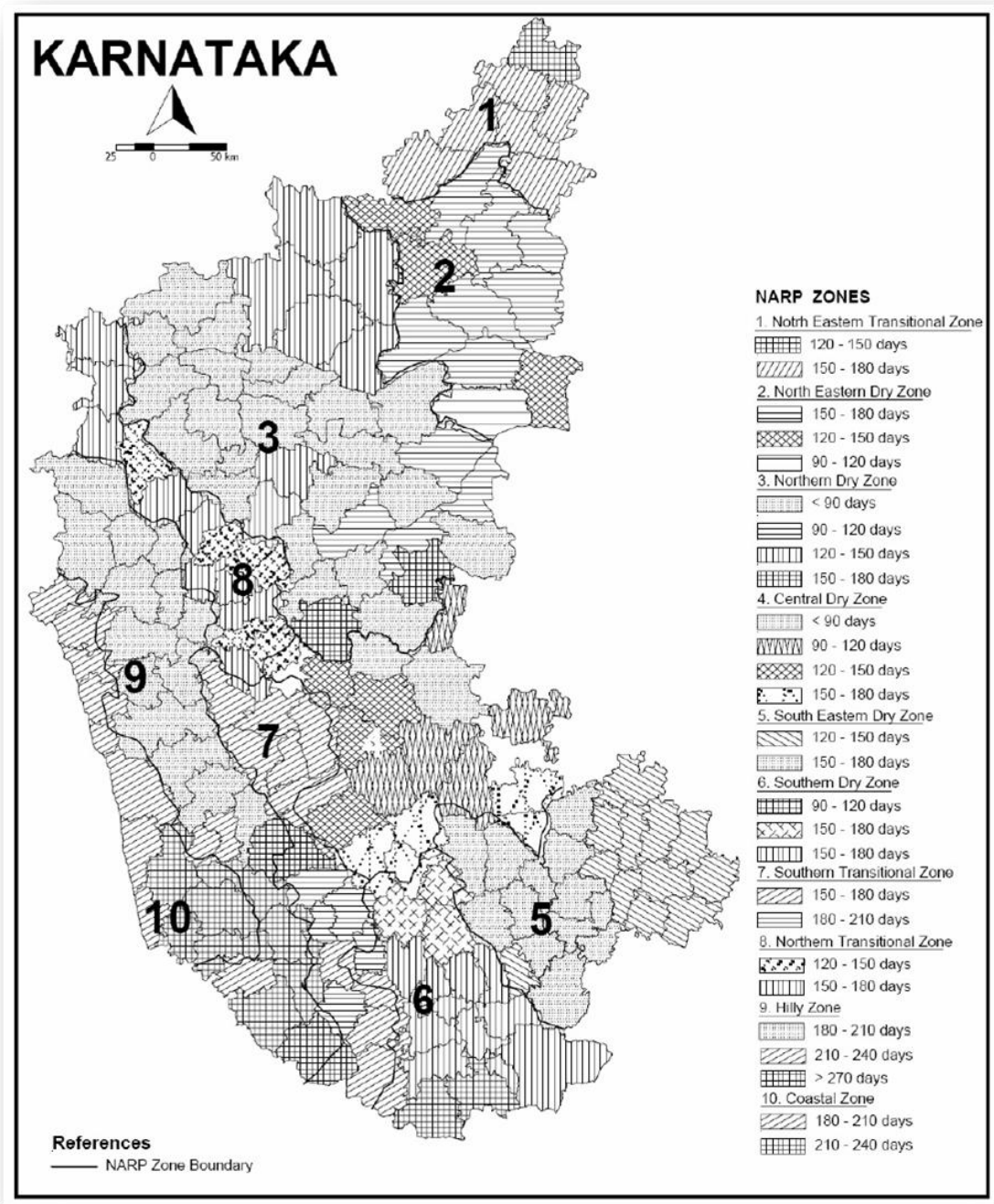

Application of required quantity of balanced NPK with deficient boron and zinc helped in proper growth and seed filling by way of improved translocation of photosynthates to sink, thereby reduced chaffy seed content and improved number of filled seeds and test weight in BMP. Similar results were discovered by Imran khan et al., (2015), Reddy et al., (2003) and Asad et al., (2003) who found an increased achene yield of sunflower by the application of boron especially at ray floret stage. Dordas and Brown (2001) observed that boron is involved in cell wall synthesis, maintenance, sugar translocation and membrane integrity and its requirement is higher for seed production. The use of boron has increased the vegetative and reproductive growth of the sunflower. BMP maintained its superiority in sunflower yield over farmer practice both in 2015-16 (31\%) and 2016-17 (40\%) and pooled data (36\%). This might be due to the stimulatory effect of boron on sunflower and in enhancing metabolic process, pollen germination and improving development of pollen tube. These results also coincide with the findings of Shekhawat and Shivay (2008) and Imran khan et al., (2015). They reported that number of 
filled seeds/head and number of achenes/head were increased with boron application because of augmentation in pollen-production capacity of anthesis and pollen grain viability. It has been also reported that boron deficiency at flowering can affect pollen viability and abortion of stamens and pistils which contributes to low seed set (Al-Amery et al., 2011).

\section{Interaction effect of soils and management practices}

BMP under black soil recorded significantly highest seed yield per plant $(15.22 \mathrm{~g} / \mathrm{ha})$, total number of seeds (413.95), number of filled seeds (366.35) and test weight $(4.57 \mathrm{~g})$ as compared to FP but which was on par with BMP with red soils. However BMP with both red and black soils proves its superiority in all yield attributes and seed yield $(1128 \mathrm{~kg} / \mathrm{ha} \&$ 1084.22 in both black \& red soils respectively) in both the years. The increment in all the yield attributes under BMP is attributed to application of balanced NPK with $\mathrm{Zn}$ and Boron. Foliar application of boron can help in the direct and rapid absorption of required amount of boron for higher production. Zinc is recognized among the important micronutrients considered as essential for the plant growth and development. Application of $\mathrm{Zn}$ increases uptake of NPK and increased seed yield of sunflower. These results are in line with Anuprita et al., (2005), Cakmak (2008) and Baraich et al., (2016). BMP in red soils gave higher yield advantage of 43 per cent as compared to black soils (30\%).

The hybrid cultivar KBSH-44 also recorded higher yield attributes over KBSH-53 This might be ascribed due to the variation in genetic makeup with respect to vegetative and reproductive growth traits of respective hybrids. These results are in line with the Reddy et al., (2002) who demonstrated an increase in plant height, stem diameter and days to maturity of hybrid 'KBSH-44'than the hybrid KBSH-1. Similarly several researchers (Reddy et al., 2002; Iqbal, 2008 and Zheljazkov et al., 2010) were also reported disparity in agronomic and productive potential for various sunflower hybrids.

\section{Agro-economics}

Highest net return (Rs. 22390) was observed in black soils as compared to red soil (Rs. 21536). Similarly, BMP recorded highest net returns (Rs. 26509) and B:C ratio (2.71) as compared to FP (net returns, Rs. 17394 and $\mathrm{B}: \mathrm{C}$ ratio, 2.29). While, BMP under black soil has recorded highest net returns (Rs. 27288) and $\mathrm{B}: \mathrm{C}$ ratio (2.76) over rest of the interactions. However, BMP with red soil also recorded $\mathrm{B}: \mathrm{C}$ ratio (2.66) and realized that next best treatment (Table 4). This is because of higher net returns under BMP due higher economic yield.

Agro-economic evaluation of sunflower indicated that black soils support better than red soils both in terms of productivity and net returns. Application of NPK based on soil test value with $\mathrm{Zn}$ and foliar application of boron (BMP) at ray floret stage and maintaining proper plant population of sunflower was found to be more profitable over farmers practice (FP). BMP irrespective of soil type could achieve higher sunflower yield and found most economical under semi-arid conditions of Northern dry zone of Karnataka plateau.

\section{Acknowledgements}

The authors thank Department of Agriculture and Cooperation, Ministry of Agriculture and Farmers Welfare, Govt. Of India for funding to carry out these studies is gratefully acknowledged. 


\section{References}

Al-Amery M. M., Hamza, J. H., and Fuller, M P. 2011. Effect of boron foliar application on reproductive growth of sunflower (Helianthus annuusL.). Int. J. Agronomy, 1-5.

Anonymous. 2006. Karnataka at a glance, Directorate of Economics and Statistics, Government of Karnataka.

Asad, A., F.P.C. Blamey and D G. Edwards. 2003. Effects of Boron Foliar Applications on vegetative and reproductive growth of sunflower. Ann. Bot., 92 (4): 656-570.

Baraich, A. A., Gandahi, A, W. Shamsuddin Tunio and Qamaruddin Chachar. 2016. Influence of micronutrients and their method of application on yield and yield components of sunflower, Pak. J. Bot., 48 (5): 1925-1932.

Cakmak. I. 2008. Enrichment of cereal grains with zinc:agronomic or genetic bio fornication. Plant Soil, 302: 1-17.

Chitdeshwari, T., and V.P. Duraisami. 2005. Impact of organic enriched micronutrient fertilization on sunflower yield, nutrient availability and uptake. Crop Res., 29(3): 431-435.

Dordas, C. and P.H. Brown. 2001. Permeability and themechanism of transport of boric acid cross the plasmamembrane of Xenopuslaevis oocytes. J. Biol. TraceElement Res., 81: 127-139.

Imran Khan, Anjum, S. A., Qardri, R. W. K., Muqarrab Ali, Chattha, M. U. and Muhammad Asif. 2015. Boosting achene yield and yield related traits of sunflower hybrids through boron application strategies. American J. Plant Sci. 6, 1752-1759.

Iqbal. 2008. Production potential of autumn planted sunflower. Ph.D. Thesis. Department of Agronomy, University of Agriculture Faisalabad.
Kaya, M. D., Kolsarici, O. 2011. Seed yield and oil content of some sunflower (Helianthus annuusL.) hybrids irrigated at different growth stages. Afr. $J$. Biotechnol 10: 4591-4595.

Kibalenko, A. P. 1972. Investigations on the influence of the boron onnucleic acid metabolism. Thaer-Arch., 14: 725-737.

Ministry of Agriculture. 2015. Crop statistics.

Muhammad Farhan Sarwar, Muhammad Haroon Sarwar, Muhammad Sarwar, Niaz Ahmad Qadriand Safia Moghal. 2013. The role of oilseeds nutrition in human health: A critical review. Journal of Cereals and Oilseeds, 4(8), 97-100.

Naidu, L.G.K., Srinivas, S. Rajendra Hegde, Devaraj, M. 2006. Assessment of Length of growing period in agroclimatic zones of Karnataka for crop planning. Mysore Journal of Agricultural Sciences, 40 (4): 520-533.

Reddy, N.Y.A., Shaanker, R.U., Prasad, T.G. and Kumar, M.U. 2003. Physiological approaches to improve harvest index and productivity in sunflower. Helia, 26, 81-90.

Reddy, S.S, Y.H. Yadahalli, V.K.K. Kumar, O. Kumara and A.H.K. Naik. 2002. Effect of fertilizer, gypsum and boronapplication on yield and economics of sunflower hybrids.Crop Research, 23 (3): 450-453.

Seiler, G. J. 2007. Wild annual Helianthus anomalus and $H$. deserticola for improving oil content and quality in sunflower. Ind. Crops Prod., 25: 95100.

Shekhawat, K. and Shivay, Y.S. 2008. Effect of Nitrogen Source, Sulphur and Boron Levels on Productivity, Nutrient Uptake and Quality of Sunflower (Helianthus annuus L.). Indian Journal of Agronomy, 53, 129-134.

Zheljazkov, V.D, B.A. Vick, M.W. Ebelhar, N. Buehring, B.S. Baldwin, T. Astatkie 
and J.F. Miller. 2008. Yield, oil content and composition of sunflower grown at multiple locations in Mississippi. Agronomy Journal, 100: 635-642.

\section{How to cite this article:}

Ramamurthy, V., G.D. Satish Kumar, M.A. Aziz Qureshi and Bhaskar, B.P. 2019. Performance of Sunflower in Relation to Soil Types and Management Levels. Int.J.Curr.Microbiol.App.Sci. 8(10): 1186-1195. doi: https://doi.org/10.20546/ijcmas.2019.810.139 